\title{
DISTRIBUTION RANGE EXTENSION OF YAGUAJAL LIMIA, LIMIA YAGUAJALI (TELEOSTEI: POECILIIDAE) FROM NORTH OF THE DOMINICAN REPUBLIC, HISPANIOLA
}

\section{Extensión de rango de distribución de la Limia de Yaguajal, Limia yaguajali (Teleostei: Poeciliidae) en el norte de República Dominicana, la Hispaniola}

\author{
Rodet Rodríguez Silva ${ }^{1 a^{*}}$, Patricia Torres Pineda ${ }^{2}$, \\ Carlos Manuel Rodríguez ${ }^{3}$, and Ingo Schlupp ${ }^{16}$
}

\begin{abstract}
'Department of Biology, University of Oklahoma, USA; *Para correspondencia: rodet.rodriguez.silva-1@ou.edu. la (Dorcid.org/0000-0002-7463-8272. "2Museo Nacional de Historia Natural "Prof. Eugenio de Jesús Marcano", Santo Domingo, Dominican Republic; (Dorcid.org/0000-0002-7921-3417. ${ }^{3}$ Ministerio de Educación Superior, Ciencia y Tecnología, Santo Domingo, Dominican Republic. ${ }^{\text {lb }}$ Corcid.org/0000-0002-2460-5667.
\end{abstract}

\section{ABSTRACT}

In this study we report two new distribution records of Limia yaguajali Rivas, 1980, a livebearing fish previously reported only from Río Yaguajal (type locality) in northwestern Dominican Republic, Hispaniola. We provide a description for an appropriate species identification and also characterize new habitats where this species was reported.

Keywords: Limia yaguajali, endemic, livebearing fish, distribution.

\section{RESUMEN}

En el presente trabajo se presentan dos nuevos reportes de distribución para Limia yaguajali Rivas, 1980. Esta especie de pez vivíparo había sido previamente reportada solo en Río Yaguajal, (localidad tipo) situado al noroeste de la República Dominicana. Además, se incluye la descripción necesaria para la identificación de la especie, así como una caracterización general de los nuevos hábitats donde se colectó la misma.

Palabras clave: Limia yaguajali, endémica, peces vivíparos, distribución.

Livebearing fishes of the family Poeciliidae (Rosen \& Bailey, 1963; Poeciliinae sensu Parenti, 1981), occur from the southern part of USA to the north of Argentina, the Greater Antilles, and Trinidad and Tobago. They are the dominant group of freshwater fish in the Caribbean islands with five genera. Two of them, Girardinus Poey, 1854 and Quintana Hubbs, 1934 are endemic to Cuba. Two others, Gambusia Poey, 1854 and Poecilia Bloch \& Schneider, 1801 are widespread distributed in Southern USA, Central America, South America, the Greater Antilles, Trinidad and Tobago and Curazao. The genus Limia Poey, 1854 which is the most speciose genus in the area with 20 species is endemic to the Caribbean and currently known from Hispaniola, Cuba, Jamaica, and Grand Cayman. Even though most Limia species occur in inland waters, some of them are tolerant to varying salinity levels and may be even found in hypersaline coastal lagoons (Haney \& Walsh, 2003; Weaver et al., 2016a). Specifically, Hispaniola is considered to be the center of endemism for Limia since at least 17 species are reported from this island whereas only one endemic species each is known from Cuba, Jamaica, and Grand Cayman each (Chambers, 1987; Burgess \& Franz, 1989; Weaver et al., 2016b). The genus shows a notable radiation in Lake Miragoane located in southern Haiti, where seven endemic species are currently reported including a species flocks within the endemic subgenus Odontolimia (Rivas, 1980). However, in the Dominican side of Hispaniola there are also many endemic species, some of them locally distributed. Limia yaguajali Rivas, 1980, for instance, so far has only been known from the Río Yaguajal in the province of Santiago Rodríguez. 
The species was named after the river where this species was first collected. There are no scientifically documented records reporting this Limia species outside of the Río Yaguajal. In this work we report two new distribution areas of L. yaguajali in the northern Dominican Republic through the analysis of key morphological traits for appropriate species identification. Some characteristics of new habitats where the species was collected are also provided.

We conducted sampling surveys in May 2018, December 2018 and May 2019 in three localities in northern Dominican Republic. We sampled Río Yaguajal and Río Cana in the province of Santiago Rodríguez, and also Río Jamao al Norte in the province of Espaillat. Fieldwork and fish collections were performed under the corresponding permit approved by Ministerio de Medio Ambiente y Recursos Naturales of the Dominican Republic. We collected fishes using a seine of $7 \mathrm{~m}$ length, $1.5 \mathrm{~m}$ height and $0.5 \mathrm{~mm}$ mesh size. We also recorded GPS coordinates for each location and described the physical structure of the aquatic and surrounding terrestrial habitat (e.g. depth of water body, presence/absence of submerged vegetation, substrate type, and type of the surrounding land use). In addition, we measured temperature and salinity (as conductivity) of each sampling point since these variables are known to be important in fish community composition. A total of 9 specimens ( 5 males and 4 females) collected in the surveyed localities were examined under an Olympus SZX7 stereomicroscope (magnification 50X) for species identification. Characters used by Rivas (1980) in the original description of L. yaguajali were measured in these specimens following the methods described by Rivas (1978). Three additional gonopodial characters for males; segments distal to the ray $3 \mathrm{keel}$, ray 4 grooved segments, and segments distal to the ray 5 keel were included in species identification (Chambers, 1987). Scale counts were done according to Miller (1948). Standard length (SL) was measured using a DigitalAid caliper (to the nearest $0.1 \mathrm{~mm}$ ). Voucher specimens were deposited in the Sam Noble Oklahoma Museum of Natural History, University of Oklahoma, Oklahoma, USA and also in the Museo Nacional de Historia Natural "Prof. Eugenio de Jesús Marcano", Santo Domingo, Dominican Republic.

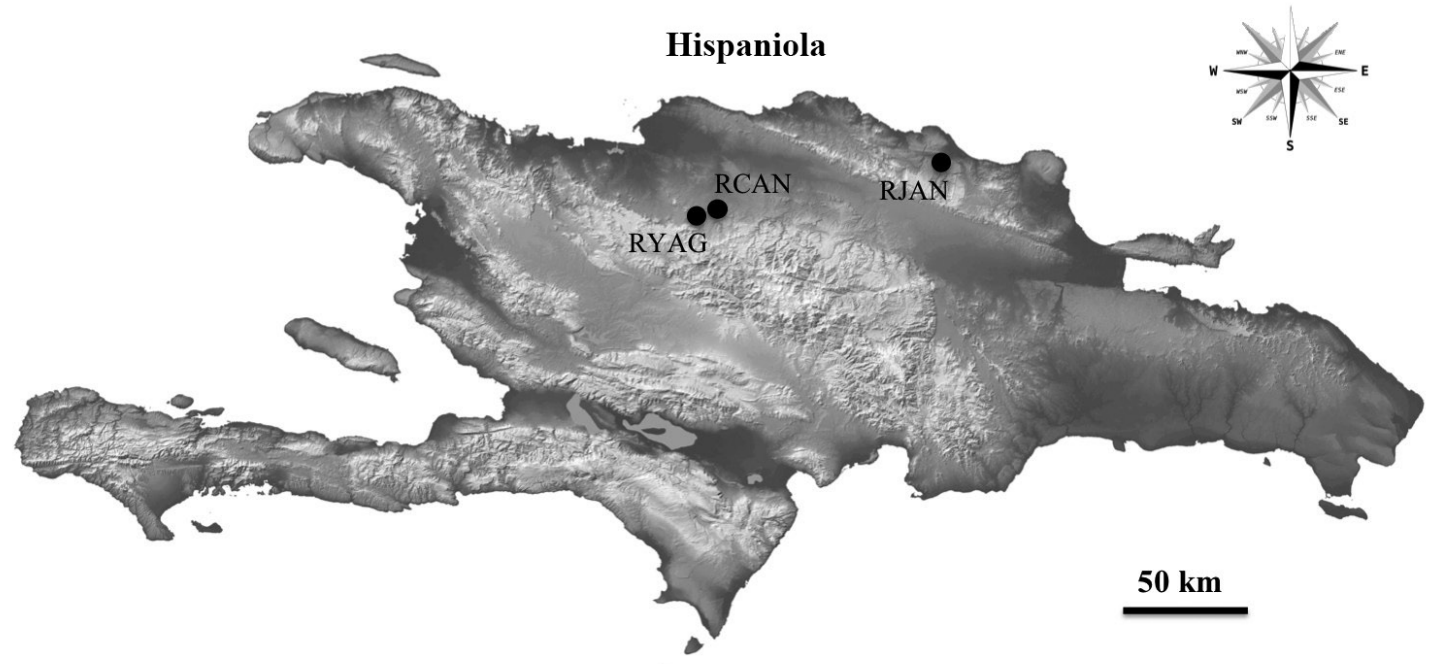

Figure 1. Sampling sites showing new distribution areas for L. yaguajali in northern Dominican Republic. RYAG: Río Yaguajal, RCAN: Río Cana, RJAN: Río Jamao al Norte. 
In this study we report two new distribution records for L. yaguajali in northern Dominican Republic (Fig. 1). The first one in Río Cana $\left(19.49604^{\circ} \mathrm{N}, 71.27964^{\circ} \mathrm{W}\right.$ ), province of Santiago Rodríguez (near Sabaneta village); the second one in Río Jamao al Norte $\left(19.63052^{\circ} \mathrm{N}, 70.44946^{\circ} \mathrm{W}\right)$, province of Espaillat (near Cabarete village).

Specimens were collected in small and shallow streams (2-3 m wide and $0.3 \mathrm{~m}$ depth). Big trees and shrubs were observed growing in the banks that provided patches of shade to the streams. A noticeable reduction in water flow was observed between the wet and dry seasons (May and December respectively). Bottom of streams were mostly covered by rocks and gravel although some muddy patches were observed as well. Values of water temperature and conductivity in wet and dry seasons for each locality are provided in Table I.

Other livebearing fishes were collected together with L. yaguajali. For instance, in Río Cana we also documented the endemics Limia zonata, Poecilia hispaniolana and Poecilia dominicensis as well as two introduced poeciliids: Poecilia reticulata (Guppy) and Xiphophorus hellerii (Green swordtail). In the Río Jamao al Norte other livebearers such as the endemic Gambusia hispaniolae and also the introduced Poecilia reticulata where found occurring in sympatry with L. yaguajali. Surprisingly we did not collect L. yaguajali either in the wet or dry season in the type locality (Río Yaguajal). Instead, other livebearing fishes were collected in that area including the relatively widespread endemic species Limia zonata as well as the introduced Poecilia reticulata and Xiphophorus hellerii.

Table I. Measurements of water temperature and conductivity in wet (month of May) and dry (month of December) seasons for each locality sampled.

\begin{tabular}{|l|l|l|}
\hline \multicolumn{1}{|c|}{ Locality } & Water temperature $\left({ }^{\circ} \mathbf{C}\right)$ & Water conductivity (microS/cm) \\
\hline \multirow{2}{*}{ Río Cana } & $\begin{array}{l}25.9 \text { (December 2018) } \\
29.3 \text { (May 2019) }\end{array}$ & $\begin{array}{l}540 \text { (December 2018) } \\
648 \text { (May 2019) }\end{array}$ \\
\hline \multirow{2}{*}{ Río Jamao al Norte } & & \\
& 25.3 (December 2018) & 528 (December 2018) \\
& & 475 (May 2018) \\
& & \\
Río Yaguajal & 28.6 (December 2018) & 583 (December 2018) \\
& 29.8 (May 2018) & 387 (May 2018) \\
\hline
\end{tabular}

L. yaguajali can be distinguished from other species of Limia by the fewer dorsal rays (usually 7) and also fewer predorsal scales (usually 11 to 13). The species has numerous branched caudal rays (usually 16) (see Table II). The ray $4 \mathrm{p}$ serrae of males usually have 11 to 12 serrae and about 17 segments distal to them. There is a palp that extends to the tip of gonopodium (Fig. 2). 


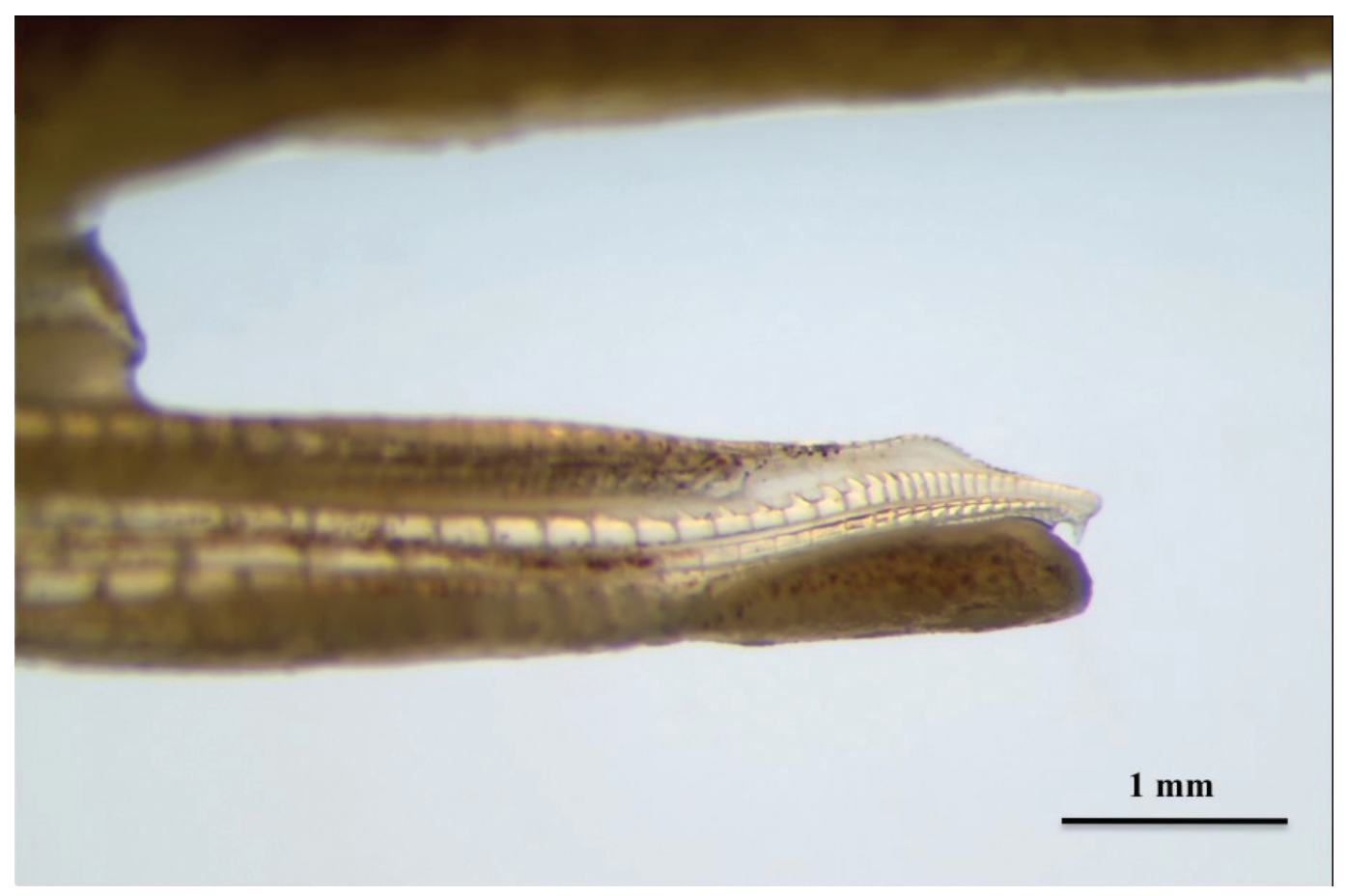

Figure 2. Gonopodium tip of a male (36.0 mm standard length) of L. yaguajali from Río Jamao al Norte.

The females have the origin of the dorsal fin slightly behind the origin of the anal fin. The males lack any distinctive mottling on the dorsal fin, which is very common in males of other Limia species (Fig. 3, A-B). The species has a color pattern similar to Limia tridens with males having yellow abdomen and dorsal fin. However, the two species are markedly different by the shape of caudal fin. L. yaguajali has truncate caudal fins whereas $L$. tridens has a largely rounded caudal fin.

The new records of distribution reported in this study for L. yaguajali represent major range extensions for the species in northern Dominican Republic. Since the description of this livebearing fish by Rivas (1980), no reports of distribution other than those related to the type locality in Río Yaguajal are found in the scientific literature. In the case of Río Cana, the distance from nearest previous record is $8.6 \mathrm{~km}$ to the northeast. However, the distance is considerably higher for Río Jamao al Norte, which is located $120 \mathrm{~km}$ northeast of Río Yaguajal. Results of this work also highlight the importance of extensive inventories of the Hispaniolan freshwater fish fauna to re-evaluate distribution ranges of native species. This sort of studies is also needed to quantify the number of invasive species and future assessments of their impact on native fish fauna. 


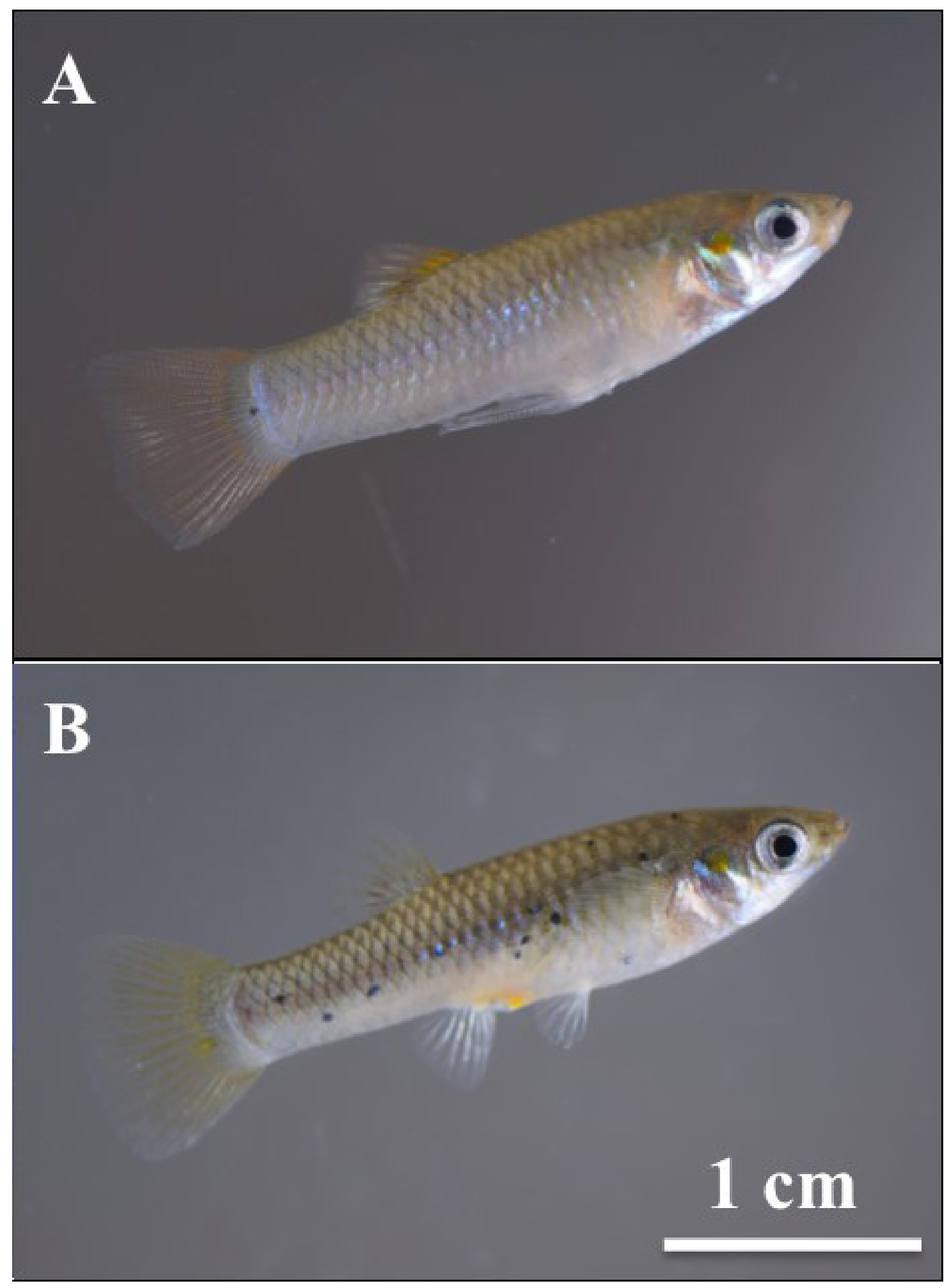

Figure 3. Live specimens of L. yaguajali collected in Río Cana. A, male. B, female. 
Table II. Meristic characters and standard lengths (SL) measured in 9 individuals of L. yaguajali from Río Cana $(\mathrm{N}=5)$ and Río Jamao al Norte $(\mathrm{N}=4)$.

\begin{tabular}{|c|c|c|c|c|}
\hline \multirow{2}{*}{$\begin{array}{l}\text { Counts } \\
\text { Dorsal rays }\end{array}$} & \multicolumn{2}{|c|}{$\begin{array}{l}\text { Río Cana }(\mathrm{N}=5) \\
3 \text { males }(27.0,28.5 \text { and } 30.0 \mathrm{~mm} \mathrm{SL}) \\
\text { and } 2 \text { females }(28.0 \text { and } 30.0 \mathrm{~mm} \mathrm{SL})\end{array}$} & \multicolumn{2}{|c|}{$\begin{array}{l}\text { Río Jamao al Norte }(\mathrm{N}=4) \\
2 \text { males }(35.0 \text { and } 36.0 \mathrm{~mm} \mathrm{SL}) \text { and } \\
2 \text { females }(40.0 \text { and } 42.5 \mathrm{~mm} \text { SL) }\end{array}$} \\
\hline & $7(5)$ & & $7(4)$ & \\
\hline Caudal rays & $15(3)$ & $16(2)$ & $15(1)$ & $16(3)$ \\
\hline Pectoral rays & $14(3)$ & $15(2)$ & $14(4)$ & \\
\hline Anal rays & $6(1)$ & $8(1)$ & $8(2)$ & \\
\hline Segments distal to ray 3 keel & $19(1)$ & $20(2)$ & $20(2)$ & \\
\hline Ray 4a grooved segments & $7(1)$ & $8(2)$ & $8(1)$ & $9(1)$ \\
\hline Ray $4 p$ serrae & $11(2)$ & $12(1)$ & $11(1)$ & $12(1)$ \\
\hline Segments distal to ray $4 p$ serrae & $14(2)$ & $15(1)$ & $15(1)$ & $16(1)$ \\
\hline Segments distal to ray 5 keel & $19(2)$ & $21(1)$ & $19(1)$ & $20(1)$ \\
\hline Lateral scales & $27(3)$ & $28(2)$ & $27(3)$ & $28(1)$ \\
\hline Pre-dorsal scales & $13(1)$ & $14(4)$ & $14(4)$ & \\
\hline Pre-orbital pores & $1(4)$ & $2(1)$ & $1(4)$ & \\
\hline Pre-opercular pores & $5(1)$ & $6(4)$ & $5(1)$ & $6(3)$ \\
\hline
\end{tabular}

\section{ACKNOWLEDGEMENTS}

We would like to thank to Ministerio de Medio Ambiente y Recursos Naturales of the Dominican Republic for kindly issuing colleting permits. Thanks to Carlos Suriel and Montrai Spikes for their support with fieldwork. This study was financially supported by the National Geographic Society (WW-054R-17) and the University of Oklahoma.

\section{LITERATURE CITED}

Burgess, G. H., \& R. Franz. 1989. Zoogeography of the Antillean freshwater fish fauna. In: C. A. Woods and F. E. Sergile (eds.), Biogeography of the West Indies: Patterns and Perspectives. Boca Raton, Florida, 263-304 pp.

Chambers, J. 1987. The cyprinodontiform gonopodium, with atlas of the gonopodia of the fihshes of the genus Limia. Journal of Fish Biology, 30: 389-418.

Haney, D. C., \& S. J. Walsh. 2003. Influence of Salinity and Temperature on the Physiology of Limia melanonotata (Cyprinodontiformes: Poeciliidae): A Search for Abiotic Factors Limiting Insular Distribution in Hispaniola. Caribbean Journal of Science, 39 (3): 327-337.

Miller, R. R. 1948. The cyprinodont fishes of the Death Valley System of eastern California and southwestern Nevada. Miscellaneous Publications Museum of Zoology, University of Michigan, 68: 7-155. 
Parenti, L. R. 1981. A phylogenetic and biogeographic analysis of cyprinodontiform fishes (Teleostei, Atherinomorpha). Bulletin of the American Museum of Natural History, 168 (4): 341-547.

Rivas, L. R. 1978. A new species of poeciliid fish of the genus Poecilia from Hispaniola, with reinstatement and redescription of $P$. dominicensis (Evermann and Clark). Northeast Gulf Science, 2: 98-112.

Rivas, L. R. 1980. Eight new species of poeciliid fishes of the genus Limia from Hispaniola. Northeast Gulf Science, 4: 28-38.

Rosen, D. E., \& R. M. Bailey. 1963. The poeciliid fishes (Cyprinodontiformes): their structure, zoogeography, and systematics. Bulletin of the American Museum of Natural History, 126 (1): 1-176.

Weaver P. F, O. Tello, J. Krieger, A. Marmolejo, K. F.Weaver, J. V García, \& A. Cruz. 2016 a. Hypersalinity drives physiological and morphological changes in Limia perugiae (Poeciliidae). Biology Open, 5: 093-1101.

Weaver, P. F., A. Cruz, S. Johnson, J. Dupin, \& K. F. Weaver. 2016 b. Colonizing the Caribbean: biogeography and evolution of livebearing fishes of the genus Limia (Poeciliidae). Journal of Biogeography, 43: 1808-1819.

[Recibido: 15 de octubre, 2019. Aceptado para publicación: 14 de noviembre, 2019] 